\title{
THE LIMITS OF FOREIGN POLICY
}




\section{THE LIMITS \\ OF FOREIGN POLICY}

The West, the League and the Far Eastern Crisis of

$$
\text { 1931-1933 }
$$




\title{
ISBN 978-1-349-01973-1 ISBN 978-1-349-01971-7 (eBook) \\ DOI 10.1007/978-1-349-01971-7 \\ (C) Christopher Thorne 1972
}

Reprint of the original edition 1972

All rights reserved. No part of this publication may be reproduced or transmitted, in any form or by any means, without permission.

First published by Hamish Hamilton Ltd 1972

First published in paperback 1973

\author{
Published by \\ THE MACMILLAN PRESS LTD \\ London and Basingstoke \\ Associated companies in New York Dublin \\ Melbourne Johannesburg and Madras
}

SBN 333150430

The paperback edition of this book is sold subject to the condition that it shall not, by way of trade or otherwise, be lent, re-sold, hired out, or otherwise circulated without the publisher's prior consent in any form of binding or cover other than that in which it is published and without a similar condition including this condition being imposed on the subsequent purchaser. 
To Pierre Renouvin and Stephen Roskill 


\section{CONTENTS}

Preface

xi

Abbreviations and References $\quad$ xix

\section{PART ONE. EXPOSITION}

1 Summary and Perspective

2 The Setting in the Far East, I

To the Washington Conference of 1921

Washington and after: China, the Soviet Union and Japan

3 The Setting in the Far East, II

Washington and after: the interests, policies and aspirations of the West

The West and the balance of power

4 The Setting in the West

Domestic politics and diplomatic resources

78

The search for peace

Retrospect

\section{PART Two. DEVELOPMENT}

5 Outbreak: From the Mukden Incident to the League Resolution of 24 October, 1931 Developments in the Far East

Public reactions in the West

The shaping of policy: London, Paris and Berlin

The shaping of policy: Washington

Retrospect

6 Deterioration: To the League Resolution of 10 December, 1931 Developments in the Far East

Public reactions in the West

The shaping of policy: London 


\section{CONTENTS}

7 The Founding of Manchukuo and War in Shanghai

Developments in the Far East

Public reactions in the West

London and Washington: information and advice

London and Washington: disposition and debate

London and Washington: interchange and decision

London and Washington: aftermath

Retrospect

8 Waiting for Lytton

Developments in the Far East

Public reactions in the West; the Lytton Commission and its Report

The shaping of policy: Washington, London and Paris 288 Retrospect

9 The West in Disarray

Disarmament, reparations and debts: public manoeuvres in the West

Internal debate, international argument, and the Far Eastern factor 310

Retrospect

10 A League Conclusion and the Departure of Japan

Developments in the Far East

Public reactions in the West

\section{Part Three. RECAPITUlation}

11 Aftermath and Progression

Developments in the Far East

The League and public opinion in the West

The shaping of policy: London and Washington 387

12 Conclusions

Bibliographies 


\section{LIST OF MAPS}

(by Patrick Leeson)

1. Manchuria, 1932

opposite page 35

2. The Far East: Strategic Setting

3. Shanghai and its Environs, 1932 


\section{PREFACE}

MY CURIOSITY concerning the Far Eastern crisis of 1931 to 1933 was first aroused by the frequent assertion that here lay the true starting point of the Second World War and the moment when the structure of international peace which had been erected after 1918 was overthrown, or betrayed, or both. In addition, I observed that since Reginald Bassett's Democracy and Foreign Policy, published twenty years ago, no close study had been made of the British involvement in this crisis, for which there were now available not only the mass of official documents in the Public Record Office but also numerous collections of private papers, including those of men like Gilbert Murray and Viscount Cecil who stood outside the ranks of regular officials, and who had been one of Bassett's principal objects of attention. No sooner had I begun to delve into this unpublished material on British Far Eastern policy, however, than it became clear that the subject was so closely interwoven with its American counterpart that any attempt to isolate the former would be unsatisfactory in many ways; at the same time I began to feel that, despite the work which had already been produced on the United States side of things, there might be something I could contribute in that sphere as well in terms of both broad perspective and detailed analysis. Rashly, therefore, I plunged deeper into the subject, to be met with great kindness and assistance from American scholars already established there. In particular I wish to thank Dr. Dorothy Borg of Columbia's East Asia Institute, to whose fine work on United States policy from 1933 onwards all students are lastingly indebted, and with whom I was able to spend several days of invaluable discussion in New York.

Besides developing a comparison of British and American policies and policy-making in this way, I was also able to broaden the study in directions that were suggested by three other considerations: the role of the League of Nations and of Britain within that organisation; the complex connections, not yet adequately explored, I felt, between Far Eastern affairs and the shifting, triangular relationship between the United States, Britain and France; and above all the entire Western presence in the Far East, with its attendant images of and approaches to that part of the world. Again, I was fortunate to be able to get at newly-available or unused archive material, even if the means had sometimes to be circuitous and the result on occasions was disappointing. In the case of the League collection at Geneva (for which a 40-year rule operates), there proved to be more quantity than quality. In Paris (where a 30-year rule now obtains, but only in theory) my search was 
made possible only by the great kindness of Professor Pierre Renouvin, chairman of the commission which is engaged in publishing the series of Documents Diplomatiques Français, who worked on my questions in areas of the Quai d'Orsay archives which are at present forbidden to outsiders. Our correspondence and discussions on the spot have provided a pleasure which is inadequately repaid in the dedication of this book.

Meanwhile on German policy concerning the crisis there was the substantial amount of photostat material from the Foreign Ministry in Berlin which is preserved by the Foreign Office in London. In general, however, the German line in 1931-3 was to keep out of the affair as far as possible, and since this was obviously even more the case with the Italians-except where matters of show were concerned, as touching on their usual pretence to Great Power status-I forebore to pursue my enquiries in Rome. For the Dutch, on the other hand, Far Eastern events clearly held great significance, and for enabling me to overcome the language problem involved I am most grateful to Dr. M. J. Meijer, until recently Counsellor of the Netherlands Embassy in Tokyo and a specialist in Chinese law, who both alone and with me impatiently at his elbow toured the archives of The Hague in search of relevant material. Alas, the number of available documents which contain comment, and not simply factual report, is slender in the extreme, even where communications between the home government and Batavia were concerned. To a large extent this is a result of burnings carried out in May 1940; enough material has survived, however, to make it plain that Dutch policy at the time amounted to little more than resolute, cryptic and anxious passivity-disappointing for the historian, but no doubt sensible in the circumstances, and in itself something of a saving in bureaucratic stationery.

The focus of my work has thus been on the West, and I can make no claim to have contributed in pioneering fashion to the actual Far Eastern aspects of the crisis. Even so, I was anxious to measure the various Western estimates of what was occurring against the situation as it is now known to have existed in Japan, Manchuria and the remainder of China. In this respect the massive and unpublished documentation and proceedings of the International Military Tribunal that sat in Tokyo after the war provided one important source-though suspect in various respects. In addition, however, I must acknowledge my general debt to those Far Eastern specialists whose studies, of Japanese policy in particular, are cited throughout the book. My own access to Japanese-language sources has also been made possible through the tenacity and cheerfulness of my student, Haruko Kinase, who translated for me key sections of the multi-volumed Taiheiyo senso e no michi: kaisen gaiko-shi, and through the kindness of James Morley, Director of Columbia's East Asia Institute, who allowed me to read in typescript such portions of the same work as have been translated for eventual publication in edited form. Dr. Shumpei Okamoto, who is one of those engaged in this Columbia project, also encouraged me to invade his home in order to read and discuss these matters far into a Philadelphia evening.

Having thus broadened the enquiry to take in Western policies as a whole and set them against Japanese developments, I found myself required to go back into at least the preceding thirty years or so in order to establish an adequate framework within which to examine the commitments, resources 
and attitudes of these Western states during the comparatively brief period of the crisis itself. The Manchurian episode was to raise such broad questions concerning both collective security and international politics in the Far East that I felt bound to offer more than a brief, preliminary nod in that direction, however much this meant incurring further debts to existing works. Too often, it seemed to me, the events of 1931-3 had been looked at simply in the light of the crises that followed, culminating in the Pacific war of 1941. Such a perspective appeared to have given rise to various facile claims and criticisms which began to lose much of their substance if one did not start with the notion of 1931 as a sudden 'turning point'; in addition, it was a perspective which I felt had sometimes led to certain underlying issues being played down or neglected entirely. Hence, the first quarter of this book searches back in a way which is, of course, instinctive and proper for any self-respecting historian. At the same time, however, both this section and the remainder of the work also represent an attempt to bring together a number of closely related studies in foreign policy analysis, a subject which, in Britain at least, remains sufficiently unfamiliar to require a brief word on the approach $\mathrm{I}$ have adopted in that connection.

In common with many who have been trained as historians, I have to admit to a deep scepticism regarding the search which is being conducted by some political scientists for general theories and predictive formulae that can be applied to international relations. If historians themselves can often become lost in minutiae, then equally, the designing of theoretical patterns at a quasi-theological level can degenerate into a self-indulgent and fruitless pastime, however attractive the notion of discovering all-embracing explanations and solutions for international conflict, say, in an age when such a phenomenon threatens to destroy mankind itself. And while so-called 'laws' of international relations as a whole are unlikely to rise above trivial generalisations, the theoretical structures which have been erected around a particular subject such as foreign-policy decision-making are often open to serious objections: they tend to be unduly static, for example, to allow insufficiently for the on-going nature of foreign policy, where the conscious, major decision is the exception rather than the rule, and to have nothing to offer when it comes to weighing the relative significance of any one factor on a specific occasion. Or to take another field of enquiry which is rapidly being extended, not all students of game theory are modest enough to admit as Anatol Rapoport has done that the practical application of such principles in international relations 'is beset with well-nigh insuperable difficulties', ${ }^{1}$ while their application in the study of past decisions would scarcely seem to be any more fruitful.

Yet despite the various objections which are rightly raised against some of the claims that have been made for theoretical approaches to international relations, the more traditional discipline of narrative diplomatic history, even when practised by a master of that craft, is surely also open to question in a number of respects. For example, many such studies-and I do not except my own-have often adopted a brusque approach (apparently supported by a number of unstated and perhaps unrecognised assumptions)

${ }^{1}$ A. Rapoport, 'International Relations and Game Theory', in B.B.C., Decision Making (London, 1967). 
where causality is concerned, and in this context have failed to make use of work being done in neighbouring areas of study such as social psychology. Or again, that approach to international history which treats states as so many billiards balls, each one a discrete unit with its own neat and readymade set of aims and interests, bears little relation to the world of international politics as it now exists-or perhaps ever existed. And if this last kind of exercise is now dying away, the immensely complex nature of foreign policy formulation (whether or not perceived as such by those concerned) is still frequently simplified to the point of falsification, either by isolating a single aspect of that policy from all other issues that were having to be faced by officials at the time, or by ignoring the interplay between international factors and those arising within domestic politics. Theoretical models of such a subject have their dangers, but provided they are flexible enough always to respond to and be refined by the material to which they are applied, an initial scheme of analysis of this kind can at least assist the student in recognising and finding his way through the plethora of considerations to which foreign policy gives rise.

In addition to being a historical study of the crisis of 1931-3, therefore, the present work attempts to show some awareness of what Stanley Hoffmann has called 'the long road to theory' in international relations, ${ }^{1}$ and I have acknowledged my broad debt to a number of relevant works in a separate bibliography. Nevertheless I have tried not to let the scaffolding of foreign policy analysis obtrude on the reader's attention in the finished product. It is enough to mention here that an attempt to reveal the various layers that can be present in an international exchange will sometimes involve returning to a single episode from several different directions, and that a basic pattern has been followed in this respect in Part Two of the book, which deals with the crisis itself. Within each chronological section, events in the Far East are first outlined in the form in which they were publicly known in the West at the time, and are followed by an account of the manoeuvrings-between the Japanese army in the field and the government in Tokyo, say-that were taking place behind the scenes. By moving on from there to an account of how individual Western governments and the League of Nations reacted publicly to these events, I hope to enable the newcomer to the period to orientate himself at the outset; he will also then have the knowledge with which to embark upon an examination of how non-official pressure-groups, individuals and newspapers in various countries themselves reacted to what they saw as happening in both East and West. Finally, one turns to the way in which the policy of each government was arrived at, the views that were held in official circles of the foregoing domestic opinion, the information and advice that was being received in private from abroad, the options that were seen as being open and the reasons for whatever choice-or the refusal to choose-that was then made. At times, of course, the pattern of events requires a change in that of presentation, so that during the Shanghai crisis in 1932 it is the comparison of British and American policies and the

${ }^{1}$ S. Hoffmann, 'International Relations: The Long Road to Theory', in J. N. Rosenau (ed.), International Politics and Foreign Policy (New York, 1961). Cf. K. Knorr and J. N. Rosenau (eds.), Contending Approaches to International Politics (Princeton, 1969), esp. the essay by D. Vital. 
exchanges between those two countries which are brought to the fore. In brief, the book does not have a purely narrative framework, nor does it fashionably attempt to measure the factors involved to four places of decimals, however disappointing the result may be to unyielding champions of each of these extreme approaches to international relations. If it contributes in some small way to bridging the gap between historians and others in this area of study, then I shall be pleased enough.

Explanations completed, I can turn to the more straightforward and rewarding task of acknowledging my debt to those who were themselves involved in some way in the Far Eastern crisis and who, between them, have given up many hours to answering my questions, either by letter or in interview or often both. Occasionally it transpired that the passage of forty years had considerably narrowed the memory, although it was a help in itself when this was readily admitted; in some instances, and notably where Mr. NoelBaker is concerned, my own interpretation has come to diverge sharply from the one offered to me by a participant in the event; at no time have I relied upon oral testimony for a major point without extensive documentary support. Nevertheless, my 'feel' of the subject has been greatly enhanced by those concerned, and my warm thanks are due to Ambassador Thanassis Aghnides, then Head of the Disarmament Section of the League Secretariat; to Dr. Salvador de Madariaga, who was a major contributor to the debate at Geneva in his capacity as a member of the Spanish delegation there; to Ambassador René Massigli, who performed a similar service for France and was Head of the League of Nations Department in the Quai d'Orsay; to F. P. Walters, later Deputy Secretary-General and historian of the League, who was then Chef de Cabinet to the Secretary-General, Sir Eric Drummond ; to Adrianus Pelt, one of those officials of the League Secretariat who accompanied the Lytton Commission to Manchuria, and to Major-General William Biddle of the U.S. Army, who also accompanied that Commission as a Lieutenant and aide to the American member, General McCoy; to E. H. Carr, who in 1931-3 was Assistant Adviser on League of Nations Affairs in the British Foreign Office, and to Sir Frank Roberts, who was then a junior official in the Far Eastern Department of that same organisation ; to Clark Eichelberger, then a senior official of the American League of Nations Association, Philip Noel-Baker of the British League of Nations Union (who was also personal assistant to Arthur Henderson, President of the Disarmament Conference), and Walter Lippmann, whose private correspondence with the Secretary of State and others was almost as extensive as his public comments on the course of the crisis. Finally, with the leading Far Eastern officials of the State Department at the time no longer being available to be plagued with my questions, Professor George Kennan kindly allowed me to try out on him some of my tentative conclusions concerning the American Foreign Service, of which he was then a member. I hope that these and other surviving participants in the events recorded below will forgive my referring to them in the text in the style usually accorded to historical figures.

I must further express my gratitude to the following for granting me permission to quote unpublished, copyright material: Her Majesty the Queen; M. Thanassis Aghnides; Earl Baldwin of Bewdley; E. H. Carr, Esq.; 
Lord Chatfield and the Dowager Lady Chatfield; Lord Hankey; the Harvard College Library; Professor Ann Lambton; the Librarian and trustees of the Austen Chamberlain Papers, Birmingham University Library; Walter Lippmann, Esq.; Mrs. Dorothy Lloyd; Malcolm MacDonald, Esq.; the Rt. Hon. Philip Noel-Baker; Mrs. Trekkie Parsons; Lord Simon; the Stimson Literary Trust, and Dr. Arnold Toynbee. I have not in every case been able to trace if and where rights over material are reserved, and should there remain those whose permission I ought to have obtained, I ask them to accept a belated apology.

My thanks also go to the staff of the numerous archives and libraries in which I have worked on this study. Without their ready assistance my task would have been difficult in the extreme, and I hope they will understand if I do not name them here individually, their institutions being set out in the list of sources at the end of the book. I would like to mention in particular, however, those who have helped me in four major centres: the Public Record Office in London, the National Archives and Library of Congress in Washington, and the library of Chatham House, where I obtained much of my secondary material. In addition, I must thank Miss Dale Anderson of the East Asia Institute of Columbia University; Hugh Collar, Esq., former Secretary of the China Association, who guided me in the workings and records of that body; Victor-Yves Ghébali of the Carnegie Foundation's Geneva centre; the Hydrographer's Department of the Royal Navy, which supplied distances for the strategic map of the Far East; Captain Kent Loomis, U.S. Navy, who advised me on the archives of that Service; Dr. Herman Kahn, former Director of the Roosevelt Memorial Library at Hyde Park, who spared me unnecessary labours there; David Marquand, M.P., who allowed me to work on the MacDonald Papers in his London home; Professor A. Temple Patterson, who made the Chatfield Papers available to me, and C. H. Rolph, Esq., in whose home I read material from the Kingsley Martin Papers. I am also most grateful to my colleague, Dr. John Chapman, and to Professor James Crowley of Yale for advice at an early stage of my enquiries.

There remain three other scholars to whom I am particularly indebted, however necessary and proper it is for me to add that the responsibility for everything that follows is mine alone. Dr. Ian Nish of the London School of Economics, having already written two outstanding studies of AngloJapanese relations in earlier periods on which I could lean, now offered valuable comments on the more particularly Far Eastern portions of my typescript. An even greater labour was undertaken by Professor Akira Iriye of the University of Chicago, who found time to read the entire book and to give me the benefit of his extensive knowledge of trans-Pacific relations between the wars. Finally, at all stages of the work I have received from Captain Stephen Roskill of Churchill College, Cambridge, encouragement extending far beyond those matters concerning naval policy and Sir Maurice Hankey that sent me to him in the first place. To him, as to Pierre Renouvin, I offer this book as a tribute to both scholarship and kindness.

The widespread investigations on which this book is baseci would not have been possible without an award from the Social Science Research Council. The University of Sussex also helped to meet the cost of some of my travels 
within Europe, thus conniving at a somewhat free rendering of its motto, 'Be Still and Know', as well as granting me a term's leave of absence in which to complete the final draft. These same travels from one archive to another were greatly lightened by the hospitality of three friends and their families: Professor Robert Webb in Washington, Marshall Mascott in New York and Marcel Delessert in Geneva; in London, Christopher SinclairStevenson of Hamish Hamilton has been a most helpful partner in the enterprise. Meanwhile my own family have accepted my lengthy mental and physical absences with so delicate a blend of regret and encouragement that they leave no room for greater admiration and gratitude on my part.

January 1972

Christopher ThORNE 


\section{NOTES ON ABBREVIATIONS, REFERENCES, ETC.}

Abbreviations used in the text.
C.E.R.
Chinese Eastern Railway.
C.I.D.
Committee of Imperial Defence.
C.I.G.S.
Chief of the Imperial General Staff.
L.N.A.
League of Nations Association (U.S.A.).
L.N.U.
League of Nations Union (G.B.).
S.M.R.
South Manchurian Railway.

Abbreviations used in references.

AA.

ADM.

AQD.

CAB.

DBFP.

DDF.

DGFP.

DO.

DS.

FO.

FRUS.

IMTFE.

LN. Archives.

LNOJ.

Lytton Report.

PM.

RA.

T.
Photostat records of the German Foreign Ministry (Auswärtiges Amt.)

Admiralty records, Public Record Office, London.

Archives of the French Ministry for Foreign Affairs, Quai d'Orsay, Paris.

Cabinet, Cabinet Office and C.I.D. records, Public Record Office, London.

Documents on British Foreign Policy, 1919-1939, Second Series.

Documents Diplomatiques Français, 1932-1939, $1^{\text {re }}$ Série.

Documents on German Foreign Policy, 1918-1945, Series C.

Dominions Office records, Public Record Office, London.

Department of State decimal files, National Archives, Washington, D.C.

Foreign Office files, Public Record Office, London.

Foreign Relations of the United States.

International Military Tribunal for the Far East, mimeographed records, Imperial War Museum, London.

League of Nations Archives, Palais des Nations, Geneva. League of Nations Official Journal.

League of Nations, Appeal by the Chinese Government: Report by the Commission of Enquiry.

Prime Minister's files, Public Record Office, London.

Royal Archives, Windsor Castle.

Treasury files, Public Record Office, London. 


\section{Further notes}

Unless otherwise stated, numbers in references are to pages. In order to reduce the weight of footnotes a little I have included full details of sender, recipient and date only where such information appeared to be of immediate value to the reader; elsewhere, only the document and file or volume number is given. Where no file or box number is given for personal papers, it indicates the absence of any permanent classification scheme.

I have given Japanese names in the text in their native version, that is with the surname before the given name; on the other hand I have not included Japanese accents, which would be meaningless to the great majority of readers and which to the remainder will be obvious in their absence. In references, I have distinguished between matter obtained from the original, Japanese volumes, Taiheiyo senso e no michi, and that obtained from the incomplete and edited translation in the East Asia Institute, Columbia University, 'The Road to the Pacific War'. The Times refers to the London paper, the New York Times being given in full. For the sake of brevity I have generally used the term 'Far East' as spilling over to embrace also those parts of South East Asia and Australasia that were likely to be involved in any major conflict between Japan and Western powers; when dealing specifically with any one of these areas I have named it in the more usual way. Although the Soviet Union lies to the West of China, it is not included within my use of the term, 'the West'.

Unless otherwise stated, the times given are local. In order to arrive at the relative situation, the following variations from Greenwich Mean Time should be applied: Geneva, +1 hour; Hongkong, Philippines and Shanghai, +8 hours; Japan and Manchuria, +9 hours; New York and Washington, - 5 hours; San Francisco, - 8 hours. 
'I remember in particular one long and violent argument on evolution, in the reality of which Lawrence always passionately disbelieved. "But look at the evidence, Lawrence," I insisted, "look at the evidence." His answer was characteristic. "But I don't care about evidence. Evidence doesn't mean anything to me. I don't feel it here." And he pressed his two hands on his solar plexus.'

Aldous Huxley, introduction to The Letters of D. H. Lawrence

'We have of the universe only formless, fragmentary visions, which we complete by the association of arbitrary ideas, creative of dangerous suggestions.'

Marcel Proust, À la Recherche du Temps Perdu (trans. C. K. Scott Moncrieff, 1969 edition, vol. 11, 218). 